\title{
EFEK INOKULASI Rhizoctonia solanii TERHADAP KANDUNGAN KARBOHIDRAT TERLARUT TOTAL PLANLET KACANG PANJANG (Vigna unguiculata (L.) Walp.) SECARA IN VITRO
}

\author{
Endang Nurcahyani ${ }^{1}$, Muhamad Rizkci Sazilly ${ }^{2}$,Salman Farisi ${ }^{2}$, Rochmah Agustrina ${ }^{2}$ \\ ${ }^{1}$ Program Studi Biologi Terapan, Jurusan Biologi, FMIPA, Universitas Lampung \\ ${ }^{2}$ Program Studi Biologi, Jurusan Biologi, FMIPA, Universitas Lampung \\ endang.nurcahyani@fmipa.unila.ac.id
}

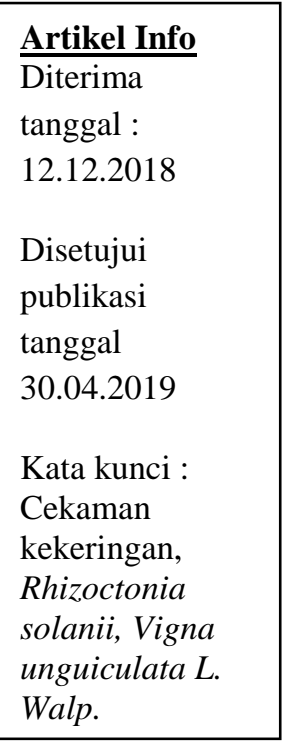
bahwa inokulasi pada akar mikoriza Rhizoctonia solanii tidak memberikan pengaruh pada kandungan karbohidrat terlarut total planlet kacang panjang terhadap cekaman kekeringan.

\section{ABSTRACT}

Constraints faced in producing long beans include a prolonged dry season. Rhizoctonia solanii mycorrhiza can help absorb nutrients and water for plants. Poly Ethylene Glykol (PEG 6000) is given to tissue culture medium to stimulate drought stress. This study aims to determine the effect of the inoculation of Rhizoctonia solanii on the dissolved carbohydrate content of total long bean plantlets given PEG 6000 in vitro. This research was conducted using a basic factorial Randomized Complete Design (RALF) consisting of 2 factors namely factor $V$; without inoculation of Rhizoctonia solanii / Control (V0), and Inocution (V1), factor P; PEG 0\% Control (P1), 15\% (P2), 30\% (P3). This research was conducted with 4 repetitions. The parameters observed in this study were total dissolved carbohydrate content. The data obtained were homogeneous using the Levene test, then continued the ANOVA test at the 5\% real level, if it was significant then the Advanced test was carried out at the BNJ level of 5\%. The results showed that the mycorrhizal inoculation of Rhizoctonia solanii had no significant effect on total dissolved carbohydrate content, whereas PEG 6000 did not significantly affect the total dissolved carbohydrate content. Based on the results of the study it can be concluded that the inoculation of the root Rhizoctonia solanii mycorrhizae did not have an effect on the total carbohydrate dissolved content of the long bean plantlets against drought stress.

doi: http://dx.doi.org/10.23960/aec.v4.i1.2019.p81-90

Anal.Environ.Chem.Anal.Environ.Chem 


\section{PENDAHULUAN}

Kacang panjang (Vigna unguiculata (L.) Walp.) adalah tanaman hortikultura yang sering dikonsumsi pada masyarakat Indonesia sebab mudah diolah dan kaya nutrisi seperti karbohidrat, vitamin, protein, lemak nabati, dan mineral. Kacang panjang, terutama bagian biji dan polongnya berfungsi sebagai pengatur metabolisme tubuh, dan memperlancar proses pencernaan bagi tubuh manausia (Kurdianingsih et al., 2015). Berdasarkan data dari Badan Pusat Statistik Indonesia (2018), pada tahun 2015 produksi rata-rata kacang panjang di Indonesia sebesar 395.524 ton sedangkan tahun 2017 produksi rata-rata kacang panjang di Indonesia sebesar 381.185 ton. Penurunan produksi kacang panjang diketahui antara lain karena musim kemarau yang mengakibatkan kurangnya ketersediaan air pada lahan.

Air merupakan salah satu faktor penting pada pertumbuhan tanaman kacang panjang, pembentukan polong, dan lainnya. Didalam tanah, air juga dapat melarutkan unsur hara dan membawanya masuk ke dalam jaringan tanaman melalui akar. Kondisi kurangnya air akibat keterbatasan ketersediaan air lingkungan tumbuhan (medium tanam) disebut dengan cekaman kekeringan. Pada saat musim kemarau, penyerapan air berkurang terus menerus sementara pemasok air ke dalam tanah lahan terus menerus terjadi. Air tanah akan menguap mengakibatkan lahan kering dan jika berlangsung dalam waktu lama pertanaman akan pertumbuhan tanaman menurun dan bahkan menyebabkan mati (Sinaga, 2015).

Salah satu alternatif yang efektif dan efisien untuk mengatasi cekaman kekeringan pada tanaman yaitu dengan menggunakan varietas yang tahan terhadap kekeringan. Cara untuk mendapatkan bibit yang tahan terhadap kekeringan dapat dilakukan dengan menggunakan teknik in vitro. Seleksi cekaman kekeringan pada teknik in vitro dapat dilakukan dengan cara pemberian agen penyeleksi ke dalam medium tanam (Muliani et al., 2014).

Poly Ethylene Glycol (PEG) digunakan untuk membuat suatu kondisi cekaman kekeringan dengan menurunkan potensial air pada medium dalam percobaan kultur jaringan tumbuhan (Zulhilmi et al., 2012). Penambahan PEG diharapkan dapat memberikan simulasi cekaman kekeringan seperti yang terjadi di alam, sehingga tanaman memberikan respons terhadap cekaman kekeringan (Rahayu et al., 2005).

Penggunaan teknik in vitro atau kultur jaringan dalam mempelajari cekaman kekeringan memiliki keuntungan yaitu dapat membuat medium tanam steril tidak ada mikroorganisme yang 
merugikan, dapat digunakan untuk melakukan simulasi cekaman kekeringan dengan menggunakan Poly Ethylene Glycol (PEG), dan menghasilkan bahan tanam unggul secara massal dan cepat (Putri, 2015).

Pada tanaman yang mengalami cekaman kekeringan, tanaman berasosiasi dengan mikoriza arbuskular untuk membantu meningkatkan unsur hara dan air dari dalam tanah melalui hifa yang terikat dijaringan akar dan batang. Rhizoctonia solanii merupakan salah satu jenis mikoriza arbuskular yang dapat menginfeksi tanaman kacang panjang pada jaringan akar dengan hifa intraselular. Pemberian mikoriza arbuskular diharapkan dapat memberikan solusi pada tanaman yang mengalami cekaman kekeringan sehingga penggunaan air lebih efisien dan mampu meningkatkan produktivitas tanaman.

\section{METODE}

\section{Alat dan Bahan}

Alat utama yang digunakan dalam penelitian ini meliputi Autoklaf, Laminar Air Flow (LAF), glassware, pipet gondok, kertas saring, pinset, pipet tip, spektrofotometri (Shimdzu UV 800), waterbath, dan timbangan analitik. Bahan yang digunakan yaitu bijkacang panjang (Vigna unguiculata (L.)Walp) isolat mikoriza Rhizoctonia solanii.yang diperoleh dari koleksi di Temanggung, medium Murashige and Skoog (MS) "use ready", akuades, sukrosa, agar, asam chlorida $(\mathrm{HCl})$, Kalium Hidroksida $(\mathrm{KOH})$, methylene blue dan alkohol $70 \%$.

\section{Prosedur}

Medium yang digunakan dalam penelitian ini adalah Murashige \& Skoog (MS) "use ready”. Untuk pembuatan medium 1 liter dibutuhkan MS “use ready” sebanyak 4,43 gram,yang dilarutkan dengan sukrosa $30 \mathrm{~g} / \mathrm{l}$, dan akuades sebanyak 1 liter dalam beaker glass, kemudian medium yang sudah dilarutkan, diukur pH nya hingga 5,7 (Jika terlalu asam ditambahkan KOH 1 $\mathrm{N}$, namun jika medium terlalu basa ditambahkan $\mathrm{HCl} 1 \mathrm{~N}$ ). Larutan tersebut kemudian dipindahkan ke dalam wadah yang lebih besar kemudian ditambahkan agar-agar sebanyak 7 g/l, dan Plant Preservative Mixture (PPM) 0,5 ml/l. Larutan medium dipanaskan untuk melarutkan agar-agar (sambil diaduk) sampai mendidih. Penambahan Zat Pengatur Tumbuh(ZPT) dilakukan setelah larutan medium diangkat, kemudian dituangkan ke dalam botol kultur sebanyak 20 
$\mathrm{ml} /$ botol. Sterilisasi medium menggunakan autoclave dengan tekanan $17,5 \mathrm{psi}, 121^{\circ} \mathrm{C}$ selama 15 menit.

Medium Murashige \& Skoog (MS) padat selanjutnya ditambah Poly Ethylene Glycol (PEG) 6000 dengan konsentrasi 0\% (kontrol), 15\% , dan 25\%. Sebelum digunakan, PEG 6000 dilarutkan dengan akuades pada konsentrasi tertentu disaring menggunakan syringe filter yang mempunyai diameter $0,45 \mu \mathrm{m}$ sebanyak 2 kali, dilanjutkan filter berdiameter $0,22 \mu \mathrm{m}$ satu kali. Penyaringan dilakukan dalam ruang steril didalam LAF Cabinet. Selanjutnya PEG 6000 ditambahkan ke dalam medium MS. Sebelum digunakan, medium diinkubasikan selama 7 hari pada suhu kamar $\left(25^{\circ} \mathrm{C}\right)$ untuk memastikan bahwa PEG 6000 telah tersaring dengan baik. Apabila dalam waktu 7 hari tidak terjadi kontaminasi pada medium, maka medium dapat digunakan.

Kemudian ditambahkan larutan isolat Rhizoctonia solanii yang dimasukkan pada medium Murashige \& Skoog (MS) sebanyak 0,1 ml dengan konsentrasi 2,3 x $10^{6} \mathrm{sel} / \mathrm{ml}$ dan diinkubasikan pada suhu kamar selama 72 jam. Setelah itu biji kacang panjang disterilkan dengan Bayclin selama 10 menit dan akuades selama 5 menit sebanyak 3 kali.Selanjutnya eksplan ditanam di medium tanam dengan berbagai perlakuan dan masing-masing botol berisi 3 biji kacang panjang. Setelah eksplan di tanam pada medium tanam selanjutnya bagian botol ditutup menggunakan plastik bening dan diikat menggunakan karet.

\section{Pengamatan}

Pengamataan dilakukan setiap 3 hari sekali selama dua minggu setelah penanaman. Parameter yang diamati dan diukur terdiri dari jumlah persentase planlet hidup dengan menggunakan Rumus 1(Nurcahyani, 2014).

Persentase planlet hidup $=$
Jumlah seluruh planlet $\quad$ Jumlah planlet yang hidup $\quad$ (1) $100 \%$

Visualisasi planlet, tinggi planlet, dan kandungan karbohidrat terlarut total dengan metode fenol-sulfur (Dubois, 1956).

Data yang diperoleh dari pertumbuhan planlet kacang panjang (Vigna unguiculata (L.)Walp) selama perlakuan dengan inokulasi mikoriza Rhizoctonia solanii dan PEG 6000 beragam konsentrasi dihomogenkan menggunakan uji Levene. Kemudian data dianalisis ragam

doi: http://dx.doi.org/10.23960/aec.v4.i1.2019.p81-90

Anal.Environ.Chem.Anal.Environ.Chem 
(ANOVA). Dilanjutkan dengan uji Beda Nyata Jujur(BNJ) pada taraf 5\% jika terdapat beda nyata antar perlakuan.

\section{HASIL DAN PEMBAHASAN}

Tanaman membutuhkan air untuk melakukan metabolisme dalam pertumbuhannya, semakin minim ketersediaan air akan mengakibatkan tanaman terganggu dalam proses metabolisme salah satunya adalah fotosintesis. Kacang panjang (Vigna unguiculata (L.)Walp) merupakan tanaman yang memerlukan air untuk melakukan proses fotosintesis yang diserap oleh akar tanaman. Saat ketersediaan air yang minim dan mengalami kekeringan tumbuhan mampu melakukan berbagai respon. Respon yang terjadi dapat berupa fisiologis, biokimia dengan menurun kandungan klorofil. Cekaman kekeringan mengakibatkan tanaman merespon secara meluas yang dimulai dari ekspresi gen yang berubah, menurunkan metabolisme laju fotosintesis dan pertumbuhannya (Pratiwi, 2016).

\section{Persentase Jumlah Planlet Hidup dan Visualisasi Planlet}

Tabel 1. Persentase Jumlah Planlet Kacang Panjang Hasil Inokulasi R.solaniiterhadap PEG 6000 Pada Beberapa Konsentrasi.

\begin{tabular}{ccccccc}
\hline \multirow{2}{*}{ Inokulasi } & $\begin{array}{c}\text { Konsentrasi } \\
\text { PEG 6000 } \\
(\boldsymbol{\%})\end{array}$ & \multicolumn{5}{c}{$\begin{array}{c}\text { Persentase Jumlah Planlet Hidup pada } \\
\text { Pengamatan ke- }\end{array}$} \\
\cline { 2 - 7 } & $\mathbf{I}$ & II & III & IV & V \\
\hline \multirow{2}{*}{ Tanpa } & 0 & $100,0 \%$ & $100,0 \%$ & $100,0 \%$ & $100,0 \%$ & $100,0 \%$ \\
\cline { 2 - 7 } Inokulasi & 15 & $83,3 \%$ & $83,3 \%$ & $75,0 \%$ & $66,7 \%$ & $58,3 \%$ \\
\cline { 2 - 7 } & 30 & $66,7 \%$ & $66,7 \%$ & $66,7 \%$ & $66,7 \%$ & $66,7 \%$ \\
\hline \multirow{3}{*}{ Inokulasi } & 0 & $83,3 \%$ & $83,3 \%$ & $75,0 \%$ & $75,0 \%$ & $75,0 \%$ \\
\cline { 2 - 7 } & 15 & $66,7 \%$ & $66,7 \%$ & $66,7 \%$ & $66,7 \%$ & $66,7 \%$ \\
\hline & 30 & $91,7 \%$ & $91,7 \%$ & $91,7 \%$ & $91,7 \%$ & $83,3 \%$ \\
\hline
\end{tabular}

Pengamatan terhadap persentase jumlah hidup dan visualisasi dari planlet yang diberi perlakuan inokulasi Rhyzoctonia dan PEG 6000 terhadap planlet kacang panjang dilakukan dengan menanam eksplan yang merupakan planlet tanaman kacang panjang pada medium Murashige and Skoog (MS) yang telah di isolat mikoriza R.solanii dan PEG 6000 dengan taraf konsentrasi $0 \%$ (Kontrol), 15\%, dan 30\%. Setiap botol kultur ditanami dengan 3 biji kacang 
panjang dan setiap perlakuan dilakukan empat ulangan. Total eksplan kacang panjang yang ditanam sebanyak 72 planlet ( 24 botol). Pengamatan jumlah planlet yang hidup dan visualisasi planlet telah dilakukan selama dua minggu dengan 5 kali pengamatan. Hasil persentase planlet kacang panjang dengan berbagai konsentrasi disajikan pada Tabel 1 dan Tabel 2.

Tabel 2.Persentase Visualisasi Planlet Kacang Panjang Hasil Inokulasi R.solanii terhadap PEG 6000 Pada Beberapa Konsentrasi.

\begin{tabular}{|c|c|c|c|c|c|c|}
\hline \multirow[t]{2}{*}{ Inokulasi } & \multirow{2}{*}{$\begin{array}{c}\text { Konsentrasi } \\
\text { PEG 6000 } \\
(\%)\end{array}$} & \multicolumn{5}{|c|}{$\begin{array}{l}\text { Persentase Visualisasi Planlet Hidup pada Pengamatan } \\
\text { ke- }\end{array}$} \\
\hline & & I & II & III & IV & V \\
\hline \multirow{9}{*}{$\begin{array}{l}\text { Tanpa } \\
\text { Inokulasi }\end{array}$} & \multirow{3}{*}{0} & $100,0 \% \mathrm{H}$ & $100,0 \% \mathrm{H}$ & $100,0 \% \mathrm{H}$ & $100,0 \% \mathrm{H}$ & $100,0 \% \mathrm{H}$ \\
\hline & & $0,0 \% \mathrm{HC}$ & $0,0 \% \mathrm{HC}$ & $0,0 \% \mathrm{HC}$ & $0,0 \% \mathrm{HC}$ & $0,0 \% \mathrm{HC}$ \\
\hline & & $0,0 \% \mathrm{C}$ & $0,0 \% \mathrm{C}$ & $0,0 \% \mathrm{C}$ & $0,0 \% \mathrm{C}$ & $0,0 \% \mathrm{C}$ \\
\hline & \multirow{3}{*}{15} & $83,3 \% \mathrm{H}$ & $75,0 \% \mathrm{H}$ & $66,7 \% \mathrm{H}$ & $58,3 \% \mathrm{H}$ & $58,3 \% \mathrm{H}$ \\
\hline & & $0,0 \% \mathrm{HC}$ & $8,3 \% \mathrm{HC}$ & $8,3 \% \mathrm{HC}$ & $8,3 \% \mathrm{HC}$ & $0,0 \% \mathrm{HC}$ \\
\hline & & $16,7 \% \mathrm{C}$ & $16,7 \% \mathrm{C}$ & $25,0 \% \mathrm{C}$ & $33,3 \% \mathrm{C}$ & $41,7 \% \mathrm{C}$ \\
\hline & \multirow{3}{*}{30} & $66,7 \% \mathrm{H}$ & $66,7 \% \mathrm{H}$ & $66,7 \% \mathrm{H}$ & $66,7 \% \mathrm{H}$ & $58,3 \% \mathrm{H}$ \\
\hline & & $0,0 \% \mathrm{HC}$ & $0,0 \% \mathrm{HC}$ & $0,0 \% \mathrm{HC}$ & $0,0 \% \mathrm{HC}$ & $8,3 \% \mathrm{HC}$ \\
\hline & & $33,3 \% \mathrm{C}$ & $33,3 \% \mathrm{C}$ & $33,3 \% \mathrm{C}$ & $33,3 \% \mathrm{C}$ & $33,3 \% \mathrm{C}$ \\
\hline \multirow{9}{*}{ Inokulasi } & \multirow{3}{*}{0} & $83,3 \% \mathrm{H}$ & $75,0 \% \mathrm{H}$ & $75,0 \% \mathrm{H}$ & $75,0 \% \mathrm{H}$ & $75,0 \% \mathrm{H}$ \\
\hline & & $0,0 \% \mathrm{HC}$ & $8,3 \% \mathrm{HC}$ & $0,0 \% \mathrm{HC}$ & $0,0 \% \mathrm{HC}$ & $0,0 \% \mathrm{HC}$ \\
\hline & & $16,7 \% \mathrm{C}$ & $16,7 \% \mathrm{C}$ & $25,0 \% \mathrm{C}$ & $25,0 \% \mathrm{C}$ & $25,0 \% \mathrm{C}$ \\
\hline & \multirow{3}{*}{15} & $66,7 \% \mathrm{H}$ & $66,7 \% \mathrm{H}$ & $66,7 \% \mathrm{H}$ & $58,3 \% \mathrm{H}$ & $50,0 \% \mathrm{H}$ \\
\hline & & $0,0 \% \mathrm{HC}$ & $0,0 \% \mathrm{HC}$ & $0,0 \% \mathrm{HC}$ & $8,3 \% \mathrm{HC}$ & $16,7 \% \mathrm{HC}$ \\
\hline & & $33,3 \% \mathrm{C}$ & $33,3 \% \mathrm{C}$ & $33,3 \% \mathrm{C}$ & $33,3 \% \mathrm{C}$ & $33,3 \% \mathrm{C}$ \\
\hline & \multirow{3}{*}{30} & $91,7 \% \mathrm{H}$ & $91,7 \% \mathrm{H}$ & $91,7 \% \mathrm{H}$ & $50,0 \% \mathrm{H}$ & $33,3 \% \mathrm{H}$ \\
\hline & & $0,0 \% \mathrm{HC}$ & $0,0 \% \mathrm{HC}$ & $0,0 \% \mathrm{HC}$ & $41,7 \% \mathrm{HC}$ & $50,0 \% \mathrm{HC}$ \\
\hline & & $8,3 \% \mathrm{C}$ & $8,3, \% \mathrm{C}$ & $8,3 \% \mathrm{C}$ & $8,3 \% \mathrm{C}$ & $16,7 \% \mathrm{C}$ \\
\hline
\end{tabular}

Berdasarkan Tabel 1 dan Tabel 2, perlakuan yang telah diberikan memperlihatkan pengaruh cukup relevan. Selama penelitian berlangsung, kendala yang dialami adalah eksplan kacang panjang yang ditanam mengalami stagnasi dimana suatu eksplan yang tidak mati namun tidak tumbuh dari mulai tanam ke dalam medium sampai waktu kurun tertentu. Stagnasi ini terjadi karena faktor dari medium yang digunakan. Menurut Arimarsetiowati (2012), medium dapat menjadi penyebab terjadinya stagnasi pertumbuhan, karena dari kondisi medium suatu sel dapat atau tidak terdorong melakukan proses pembelahan.

Pada pengamatan I, adanya jumlah persentase planlet hidup pada perlakuan tanpa inokulasi R.solanii terhadap PEG 6000 taraf $15 \%$ adalah $83,3 \%$ dan pada taraf $30 \%$ adalah $66,7 \%$, namum pada taraf $0 \%$ diperoleh persentase $100 \%$. Jumlah persentase planlet hidup juga 
pada perlakuan inokulasi R.solanii terhadap PEG 6000 taraf 0\% adalah 83,3\%, pada taraf 15\% adalah $66,7 \%$, dan pada taraf $30 \%$ adalah $91,7 \%$ dengan visualisasi planlet berwarna hijau, hijau cokelat, dan cokelat. Pada pengamatan II perlakuan yang telah diberikan tidak memperlihatkan perubahan jumlah persentase planlet hidup, visualisasi planlet hijau, hijau cokelat, dan cokelat. Pada pengamatan III memperlihatkan pengaruh perlakuan tanpa inokulasi R.solanii terhadap PEG 6000 taraf 15\% menjadi 75\%, dan perlakuan inokulasi R.solanii terhadap PEG 6000 taraf 0\% menjadi 75\% dengan visualisasi berwarna hijau, hijau cokelat, dan cokelat. Pada pengamatan IV memperlihatkan pengaruh perlakuan tanpa inokulasi R.solanii terhadap PEG taraf 15\% menurun menjadi 66,7\% namun perlakuan lain tidak memperlihatkan penurunan, visualisasi terjadi perubahan pada setiap perlakuan yang diberikan. Pada pengamatan kombinasi perlakuan terhadap planlet memberikan pengaruh pada perlakuan tanpa inokulasi R.solanii terhadap PEG 6000 taraf 15\% menjadi 58,3\%, pada perlakuan inokulasi R.solanii terhadap PEG 6000 taraf 30\% menurun menjadi 83,3\% dan terjadi perubahan visualisasi planlet pada setiap perlakuan yang diberikan.

\section{Tinggi Planlet}

Hasil uji homogenitas ragam menggunakan uji Levene pada taraf 5\%.Tinggi planlet kacang panjang yang diberikan inokulasi Rhizoctonia solanii dan PEG 6000 dengan berbagai konsentrasi disajikan pada Tabel 3.

Tabel 3. Rata-rata Tinggi Planlet Kacang Panjang

\begin{tabular}{ccccc}
\hline Inokulasi & \multicolumn{3}{c}{ Konsentrasi PEG 6000 (\%) } & Nilai \\
Rhizoctonia & $\mathbf{0}$ & $\mathbf{1 5}$ & $\mathbf{3 0}$ & tengah \\
\hline $\begin{array}{c}\text { Tanpa } \\
\text { Inokulasi }\end{array}$ & $7,58 \pm 0,53$ & $4,65 \pm 0,49$ & $4,85 \pm 0,71$ & $5,69 \mathrm{a}$ \\
\hline Inokulasi & $8,03 \pm 0,66$ & $6,03 \pm 1,66$ & $5,38 \pm 1,02$ & $6,48 \mathrm{a}$ \\
\hline Nilai tengah & $7,79 \mathrm{a}$ & $5,34 \mathrm{~b}$ & $5,12 \mathrm{~b}$ & \\
\hline
\end{tabular}

Ketererangan :

Tinggi total $=\tilde{\mathbf{Y}} \pm \mathrm{SE}$

$\tilde{\mathbf{Y}} \quad=$ Rata-rata tinggi planlet kacang panjang

SE $\quad=$ Standart error

Angka yang diikuti oleh huruf yang tidak sama berbeda nyata pada taraf 5\%

BNJ atau HSD $(0,05=2,39)$

doi: http://dx.doi.org/10.23960/aec.v4.i1.2019.p81-90

Anal.Environ.Chem.Anal.Environ.Chem 
Hasil analisis ragam menunjukkan bahwa inokulasi $R$. solanii tidak berpengaruh nyata terhadap tinggi planlet. Interaksi inokulasi dan PEG 6000 terhadap tinggi planlet adalah tidak nyata. Hal ini menunjukkan bahwa pemberian inokulasi $R$. solanii tidak memberikan pengaruh dalam meningkatkan tinggi planlet kacang panjang pada kondisi cekaman kekeringan. Pertumbuhan tinggi planlet kacang panjang terhambat akibat pemberian PEG 6000. Hal ini sesuai dengan pendapat Samanhudi (2010) menjelaskan bahwa tinggi tanaman diawali dengan proses pembelahan dan pembesaran sel. Kedua proses ini akan terjadi apabila sel mengalami turgiditas yang unsur utamanya adalah ketersediaan air. Tanaman yang mengalami kekurangan air atau ketersediaan air terbatas (cekaman kekeringan) maka pertumbuhan tinggi tanaman akan mengalami keterhambatan (Desti, 2017).

\section{Infeksi Rhizoctonia solanii Pada Akar Kacang Panjang}

Perlakuan dengan pemberian inokulasi Rhizoctonia solanii pada kacang panjang bertujuan untuk memberikan ketahanan pertumbuhan kacang panjang terhadap PEG 6000 yang dapat mensimulasi suatu cekaman kekeringan. Infeksi mikoriza Rhizoctonia solanii pada kacang panjang dapat ditemui pada perakaran tanaman.

Analisis karbohidrat terlarut total digunakan sebagai salah satu parameter untuk mengetahui ketahanan planlet kacang panjang terhadap cekaman kekeringan hasil penambahan konsentrasi PEG 6000 pada medium MS. Hasil homogenitas ragam menggunakan uji Levene pada taraf 5\%. Kandungan karbohidrat terlarut total pada planlet kacang panjang yang tanpa inokukasi dan diberikan inokulasi Rhizoctonia solanii dan PEG 6000 dengan berbagai konsentrasi disajikan pada Tabel 4.

Tabel 4. Rata-rata kandungan karbohidrat terlarut total planlet kacang panjang (Vigna unguiculata (L.)Walp) pada pengamatan minggu ke-2

\begin{tabular}{ccccc}
\hline \multirow{2}{*}{ Inokulasi } & \multicolumn{3}{c}{ Konsentrasi PEG 6000 (\%) } & \multirow{2}{*}{ Nilai tengah } \\
\cline { 2 - 4 } Rhizoctonia & $\mathbf{0}$ & $\mathbf{1 5}$ & $\mathbf{3 0}$ & \\
\hline Tanpa Inokulasi & $2,09 \pm 1,04$ & $1,77 \pm 0,89$ & $1,88 \pm 0,94$ & 1,91 \\
\hline Inokulasi & $1,90 \pm 0,95$ & $1,88 \pm 0,94$ & $1,68 \pm 0,84$ & 1,82 \\
\hline Nilai tengah & 2,00 & 1,83 & 1,78 & \\
\hline
\end{tabular}

Ketererangan :

Tinggi total $=\tilde{\mathbf{Y}} \pm$ SE

$\tilde{\mathbf{Y}}=$ Rata-rata kandungan karbohidrat total

$\mathrm{SE}=$ Standart error

doi: http://dx.doi.org/10.23960/aec.v4.i1.2019.p81-90

Anal.Environ.Chem.Anal.Environ.Chem 88 
Berdasarkan analisis ragam menunjukkan bahwa inokulasi tidak berpengaruh nyata terhadap kandungan karbohidrat terlarut total planlet kacang panjang, sedangkan PEG 6000 tidak berpengaruh nyata terhadap kandungan karbohidrat terlarut total pada kacang panjang. Interaksi antara inokulasi dan PEG 6000 terhadap kandungan karbohidrat terlarut total adalah tidak nyata. Hal ini menunjukkan bahwa pemberian inokulasi $R$. solanii tidak memberikan pengaruh dalam meningkatkan karbohidrat terlarut total planlet kacang panjang pada kondisi cekaman kekeringan.

\section{KESIMPULAN}

Berdasarkan penelitian yang telah dilakukan, dapat disimpulkan bahwa inokulasi Rhizoctonia solanii tidak memberikan pengaruh nyata pada peningkatan kandungan karbohidrat terlarut total planlet kacang panjang pada kondisi cekaman kekeringan.

\section{DAFTAR PUSTAKA}

Arimarsetiowati, R. 2012. Kultur Jaringan Tanaman Kopi. Pusat Penelitian Kopi dan Kakao Indonesia. Hal. 13-17.

Badan Pusat Statistik. 2018.Statistik Pertanian. Direktorat Pengembangan Usaha Hortikultura, Direktori Ekspor Impor Hortikultura. Jakarta : Badan Pusat Statistik

Campbell, N.A., Reece, J.B. and Mitchell, L.G. 2008. Biologi Edisi kedelapan Jilid 2. Erlangga. Jakarta.

Desti Yuniarsih. 2017. Pengaruh Cekaman Air Terhadap Kandungan Protein Kacang Kedelai.Prosiding Seminar Nasional Pendidikan Biologi. FKIP. Universitas Ahmad Dahlan.

Dubois, M., K.A. Gille, J.K. Hamilton, P.A. Rebers, dan F. Smith. 1956. Colometri method for Determination of Sugars and Related Subtance. Anal. Biochem 28(1956): 143-145.

Kurniasari, A.M., Adisyahputra, dan Rosman, R. 2010. Pengaruh Kekeringan pada Tanag Beragam $\mathrm{NaCl}$ Terhadap Pertumbuhan Tanaman Nilam. Bull. Littro 21(1).

Kurdianingsih, S., A. Rahayu, dan Setyono. 2015. Efek Pupuk Kalium Organik Cair dan Tahapan Pemupukan Kalium Terhadap Pertumbuhan, Produksi, dan Daya Simpan Kacang Panjang (Vigna sesquipedalis L. Fruhw). J Agronida 1(2).

Muliani,Y.N., F. Damayanti, dan N. Rostini. 2014.Seleksi In Vitro Enam Kultivar Kentang (Solanum tuberosum 1.) Hasil Radiasi Sinar Gamma Untuk Toleransi Kekeringan Menggunakan Manitol. Agric. Sci. J. 1(4): 71-79.

doi: http://dx.doi.org/10.23960/aec.v4.i1.2019.p81-90

Anal.Environ.Chem.Anal.Environ.Chem 
Nurcahyani, E., B. Hadisutrisno, I. Sumardi, dan Suharyanto. 2014. Identifikasi Galur Planlet Vanili (Vanilla planifolia Andrews) Resisten terhadap Infeksi Fusarium oxysporum f. Sp. Vanillae hasil seleksi in vitro dengan Asam Fusarat. Prosiding Seminar Nasional: "Pengendalian Penyakit Pada Tanaman Pertanian Ramah Lingkungan". Perhimpunan Fitopatologi Indonesia Komda Joglosemar-Fakultas Pertanian UGM. ISBN 978-60271784-0-3./2014 Hal. 272-279

Pratiwi, Asri R. 2016. Kajian Efek Poly Ethylene Glycol (PEG) 6000 Terhadap Cekaman Kekeringan Planlet Kedelai (Glycine $\max ($ L.) Merill) Varietas Tanggamus Secara In Vitro. Skripsi. Universitas Lampung. Lampung

Putri, Y. S. 2015. Pertumbuhan Kalus Stevia rebaudiana Bertoni Dari Eksplan Daun dan Ruas Batang Dengan Periode Subkultur Berbeda.Skripsi. Departemen Biologi MIPA. IPB. Bogor.

Rahayu, E. S., S.E. Gunhardja, Ilyas, dan Sudarsono. 2005. Polietilena Glikol (PEG) Dalam Media In Vitro Menyebabkan Kondisi Cekaman Yang Menghambat Tunas Kacang Tanah (Arachis hypogaea L.) Hayati (11):39-48.

Samanhudi. 2010. Pengujian Cepat Ketahanan Tanaman Sorgum Manis Terhadap Cekaman Kekeringan. Agrosains, 12(1).

Sinaga, E. 2015. Seleksi Toleransi Kekeringan In Vitro Terhadap Enam Belas Tanaman Terung (Solanum melongena L.).Hayati (11):39-48.

Yudisca Anggreiny. 2017.Identifikasi Fungi Mikoriza Arbuskular Pada Tanaman Revegetasi Lahan Penambangan Timah Di Kecamatan Merawang Kabupaten Bangka Dan Sumbangannya Pada Pembelajaran Biologi SMA.Skripsi. FKIP. Universitas Sriwijaya.

doi: http://dx.doi.org/10.23960/aec.v4.i1.2019.p81-90 